\title{
A DEIXIS ANALYSIS OF SONG LYRICS IN HELLO BY ADELE
}

\author{
Nia Kurniati ${ }^{1}$, Acep Haryudin ${ }^{2}$ \\ 1,2 IKIP Siliwangi \\ ${ }^{1}$ niakurniati@student.ikipsiliwangi.ac.id, ${ }^{2}$ haryacep@gmail.com
}

\begin{abstract}
The main purpose of this research is to analyze three types of deixis in Adele's song lyrics. Then, the song lyrics can be analyzed using pragmatic approach, especially about deixis. Then, the song lyrics can be analyzed using pragmatic approach, specifically about deixis. This research applied descriptive qualitative methodThis research applied descriptive qualitative method. The researchers elects lyrics of the most popular songs of Adele's Album 25. The data ware taken from one of three song lyrics in Adele's album 25 entitled Hello for identifying and classifying the deixis into their types (person deixis, spatial deixis, and temporal deixis). Based on the results and discussion can be concluded that all deixis found in song lyrics, there are 53 words include of kinds of deixis. the person deixis was found on adele's song as the most dominant type (43 deictic words or 75\%). Second position, deixis spatial is the most found (9 deictic words or 17\%), and in the last position is temporal deixis (4 deictic words or 8\%).
\end{abstract}

Keywords: Deixis, Song Lyrics

\section{INTRODUCTION}

Human life cannot be separated from language, people require language to be in touch and language is used as a bridge for daily interaction. In addition, people use language to share information, express their ideas, emotions or desire either in spoken or written form. According to (Ondondo, 2015) in (Wiguna et al., 2018) understanding communication and how it functions is imperative to individuals. Language also represents the personality and behavior of people as the most fundamental of human life. Furthermore, language is not only used as media of communication but also Language has been used as a appliance to convey aesthetic taste or human beauty through literary art, may be seen in advertisement and entertainment which appear in society such as music, movie and so on.

On example of entertainment media is music which is familiar in society. Music is a complex social behavior and universal that contained a human expression, ideas, opinion, and others. According to Piragasam, et al., (2013) music is a basic of human feeling, and also a routine human activity which is universally inspired with love and experience. Nowadays music has become important piece of human exertion. Music not only listened because of hobby or favorite activity however also It's considered as a friend to accompany in doing all of activities especially for youngsters like working, eating, studying or even thinking. According to Hidayah (2019) a number of lyrics in song also give an inspiration for life. According to Hidayah (2019) a number of lyrics in song also give an inspiration for life. Lyric can incorporate a progression of stanzas, the onger segments of the tune that recount to the story, and a hold back, a short expression rehashed toward the finish of each refrain. Therefore, when the individuals tune in to tune verses, some of the time they do not just attempt to capture the importance of verse itself, yet also the significance of the peruse or speaker implies. The investigation of what speakers mean or speaker significance is called pragmatics. 
Therefore, when the individuals tune in to tune verses, some of the time they do not just attempt to capture the importance of verse itself, yet also the significance of the peruse or speaker implies. The investigation of what speakers mean or speaker significance is called pragmatics.

Pragmatics is a part of linguistics which is about communicating meaning in context. According to Cruse (2006 as cited in Nasution et al., 2018) pragmatics is study about aspects of meaning which are dependents on context. Pupier (2006, as cited in Setiakawanti \& Susanti, 2018) also argued that pragmatics means implying that relies upon the setting that is methodically disconnected away from inside the development of substance or intelligent. (Yule \& Stalnaker, 1996) in (Setiakawanti \& Susanti, 2018) also stated pragmatics is a study about meaning as communication by a speaker or writer, and explained by listener or reader. In relation that, it tends to be assumed that pragmatics deals the study about contextual meaning, speaker meaning, implied meaning and the expression of relative distance.

There are some sub studies of pragmatics and one of them is deixis. According to Abdulameer (2019) Deixis is a significant piece of pragmatics that cannot be disregarded regarding language use, since its translation relies upon the specific situation and the speaker goal. Yule (1996:9) argued that define deixis derived from Greek word is implies pointing by means of language. Lugina et al., (2019) add that deixis learn about expressions of indexical or deictic in language, like you, now, today and so on. Very well may be viewed as an exceptional sort of linguistic property started up in the natural classes of individual, place. Levinson, (1983:68 as cited in Purba, 2018) There are five types of deixis. There are person deixis, spatial deixis, temporal deixis, soial deixis, and discourse deixis. and social deixis that can be utalized through uttarances, written text, drama scripts, poem, songs' lyrics, etc. In this paper, researchers focus on the three shorts of deixis, they are: person deixis, time deixis, and place deixis. The use of deixis could be found easily in english, especially in music. The deixis in Adele song is very interesting to analyze cause adele songs are very popular in the society. Three popular songs lyrics in Adele's album 25 entitled Hello, When We Were Young, and Send My Love (To Your New Lover).

\section{METHOD}

In this study, researchers was used descriptive qualitative method however characteristics of phenomena and the data were utilized using the description not numbers. According to Arikunto (2007:234) descriptive qualitative has not purpose to count the hypothesis, but just make clear some variables and condition naturally. In this research, researcher elects lyrics one of the songs of Adele's Album. The data was taken from one of three song lyrics at Adele's album 25 entitled Hello. The researcher collect the data by reading and take note. Step number one is searching the lyric on internet. The second step was choose the lyrics to be identifying and classifying the deixis into their types (person deixis, spatial deixis, and temporal deixis). The third step was calculating the kind of deixis. And after that, tabulating one of three song lyrics at Adele's album 25 .

\section{RESULTS AND DISCUSSION}

\section{Results}

Researcher proved the discovery of deixis in the song lyrics of 25 adele albums. Researcher analyzed the most popular song on Adele's 25 albums conforming to the song title, Hello, The researcher found that singers tended to use deixis types such as person deixis, spatial deixis, 
and temporal deixis used in adele song lyrics. The types of deixis used are varied and have reference meanings, detailed explanations will be presented as follow.

Table 1. Type of Deixis in Song Hello

\section{Type of Deixis}

\section{The Lyrics of the Song}

\begin{tabular}{|c|c|c|c|}
\hline & Person & Spatial & Temporal \\
\hline "Hello, it's me" & It's, me & - & - \\
\hline $\begin{array}{c}\text { "I was wondering if after all these } \\
\text { years you'd like to meet" }\end{array}$ & I, you & - & These years \\
\hline "To go over everything" & - & - & - \\
\hline "They say time's supposed to heal ya" & They & That & Time's supposed \\
\hline "But I ain't done much healing" & $\mathrm{I}$ & - & - \\
\hline "Hello, can you hear me?" & You, me & - & - \\
\hline $\begin{array}{l}\text { "I'm in California dreaming about who } \\
\text { we used to be" }\end{array}$ & I, we & In california & - \\
\hline "When we were younger and free" & $\mathrm{We}$ & - & - \\
\hline "I've forgotten how it felt" & I, it & - & - \\
\hline "Before the world fell at our feet" & Our & - & - \\
\hline $\begin{array}{c}\text { "There's such a difference between } \\
\text { us" }\end{array}$ & Us & There & - \\
\hline "And a million miles" & - & - & - \\
\hline "Hello from the other side" & - & - & - \\
\hline "I must have called a thousand times" & $\mathrm{I}$ & - & Thousand times \\
\hline $\begin{array}{l}\text { "To tell you I'm sorry for everything } \\
\text { that I've done" }\end{array}$ & You, I, I & That & - \\
\hline $\begin{array}{c}\text { "But when I call you never seem to be } \\
\text { home" }\end{array}$ & I, You & Home & - \\
\hline "Hello from the outside" & - & - & - \\
\hline "At least I can say that I've tried" & $\mathrm{I}, \mathrm{I}$ & That & - \\
\hline $\begin{array}{l}\text { "To tell you I'm sorry for breaking } \\
\text { your heart" }\end{array}$ & You, I, Your & - & - \\
\hline $\begin{array}{c}\text { "But it don't matter, it clearly doesn't } \\
\text { tear you apart" }\end{array}$ & It, it, you & - & - \\
\hline "Anymore" & - & - & - \\
\hline "Hello, how are you?" & You & - & - \\
\hline
\end{tabular}

"It's so typical of me to talk about myself, I'm sorry"

It, me, myself, I

\begin{tabular}{lcc} 
"I hope that you're well" & I, you & That \\
\hline d you ever make it out of that & You, it & That
\end{tabular}
town"

"Where nothing ever happened?"

"It's no secret that the both of us"

"Are running out of time"

It, us That

"(Highs, highs, highs, highs, lows, lows, lows, lows)"

Table 2. Deixis Kind in the Lyrics song "Hello" 


\begin{tabular}{ccc} 
Deixis Kind & Number of words & Percentage \\
\hline Person deixis & 40 & $75 \%$ \\
\hline Spatial deixis & 9 & $17 \%$ \\
\hline Temporal deisis & 4 & $8 \%$ \\
\hline Total & 53 & $100 \%$
\end{tabular}

From the table above, it can be observed the dominates in the lyric song "Hello" are: Person deixis $75 \%$, Spatial deixis: $17 \%$, Temporal deixis: $8 \%$. The highest percentage of all is Person deixis, it means that the dominant of deixis in this lyric song "Hello" by Adele's song" is Person deixis.

\section{Discussion}

The researcher found 53 words of deixis. 43 or $75 \%$ personal deixis, 9 or $17 \%$ spatial deixis, 4 or $8 \%$ temporal deixis in the Adele's song lyrics "Hello" it can be seen that the deixis type that dominates this song is person deixis and spatial deixis followed by temporal deixis. There are 11 personal deixis words I, me, myself, you, your, they, we, us, our, and it. Where there are 3 deixis words for the first person (I, me and myself), 2 words deixis for the second person (you, and your) and 5 deixis for the thirds person (we, us, our, they and it). While in spatial deixis researcher found 9 deixis words and temporal deixis 4 words.

\section{CONCLUSION}

Based on the result and discussion above, in the Adele's song lyrics, person deixis is the one most found (43 words deictic) words "I", "me", "you", "it" dominate all song lyrics, in second place, deixis spatial is the most found (9 words deictic), words "that" and "there". The third position is temporal deixis (4 words deictic).

\section{ACKNOWLEDGMENTS}

Alhamdulillahirobbil'alamin praise and to Allah SWT who always blesses me in every second of my life until I can finish this paper under the title "A Deixis Analysis of Song Lyrics in Hello by Adele". Peace and salutation to Prophet Muhammad SAW. I realize that my paper will never finish without some contribution from many people who give me motivation and guidance in order to make betterment for this paper. Therefore, I would like to express my deepest gratitude to my parents, who give me support and never stop praying for me. And thank you to my lecturer, Mr. Acep Haryudin, M.Pd, for his advices and knowledge of doing research.

\section{REFERENCES}

Abdulameer, T. A. S. A. (2019). A Pragmatic Analysis of Deixis in a Religious Text. 9(2), 292 306. https://doi.org/10.5539/ijel.v9n2p292

Hidayah, A. (2019). A Deixis Analysis of Song Lyrics in Back to You. Surakarta English and Literature Journal, 2(2), 47-55.

Lugina, G., R, E. N., \& Suprijadi, D. (2019). Deixis in the Legend of Lake Toba Story. PROJECT (Professional Journal of English Education), 2(5), 640. https://doi.org/10.22460/project.v2i5.p640-644

Nasution, D. R. A., Setiadi, G., \& Ilza, S. S. (2018). Deixis Analysis in the Song Lyrics of Ed Sheeran's Divide Album. Journal of 2nd English Language and Literature International 
Conference (ELLiC) Proceedings, 2, 376-382.

Piragasam, grace Annammal, Rosadah Abd majid, Z. M. jelas. (2013). Music Appreciation and Self- f actualization of Gifted Students. Procedia - Social and Behavioral Sciences, 90(InCULT 2012), 124-132. https://doi.org/10.1016/j.sbspro.2013.07.073

Purba, D. (2018). Deixis in John Legend's Songs. Jurnal Littera, 1, 76-84.

Setiakawanti, R. N., \& Susanti, E. (2018). Analysis Pragmatic Study on Deixis in the Articles Jakarta Sport. 1(6), 757-762.

Wiguna, A., Anggraeni, H., Nuramalia, R., \& Irma, S. S. (2018). Deixis in Maleficent Movie Script. Proffesional Journal of English Education, 1(2), 133-138. https://journal.ikipsiliwangi.ac.id/index.php/project/article/view/466 